\title{
PERBAIKAN KINERJA MELALUI BUDAYA ORGANISASI DAN KUALITAS SUMBER DAYA MANUSIA
}

\author{
Diksi Metris ${ }^{1}$, Esti Sri Mutmainah², Alvin, Ady Fauzan ${ }^{3}$ \\ ${ }^{1,2,3}$ Institut Teknologi dan Bisnis Muhammadiyah Purbalingga \\ diksi.metris@gmail.com
}

\begin{abstract}
ABSTRAK
Kebutuhan sumber daya manusia yang kompeten yang memiliki semangat, kedisiplinan, dan integritas yang baik sangat diperlukan untuk mencapai tujuan perusahaan. Dengan budaya organisasi yang baik dan manajemen kinerja yang baik akan dapat menciptakan sumber daya yang berkualitas. Penelitian ini bertujuan untuk mengetahui sejauh mana penerapan budaya perusahaan dalam menunjang manajemen kinerja surveyor. Metode penelitian ini menggunakan metode kualitatif dengan pendekatan naratif, yang memiliki karakteristik alami (natural setting) sebagai sumber data langsung, deskriptif. Hasil dari penelitian ini menunjukkan keberhasilan manajemen kinerja karyawan hampir selalu dikaitkan dengan budaya yang kuat. Berdasarkan analisa SWOT diketahui bahwa salah satu strategi yang perlu dijalankan oleh Asuransi Astra Buana adalah memanfaatkan budaya perusahaan yang baik dan kemampuan SDM yang dimiliki untuk menghasilkan layanan yang terbaik pagi pelanggan dan juga meningkatkan kinerja surveyor. Penerapan visi, misi, budaya perusahaan, strategi layanan, dan tata nilai perusahaan yang baik ini merupakan perwujudan dari penerapan manajemen sumber daya manusia yang telah dijalankan dengan baik di PT. Asuransi Astra Buana dan dapat menunjang manajemen kinerja Surveyor.
\end{abstract}

Kata Kunci: budaya perusahaan; manajemen kinerja; surveyor.

\section{PENDAHULUAN}

Pertumbuhan sarana transportasi di Indonesia saat ini menunjukkan peningkatan yang cukup pesat karena hampir di setiap aktifitas, manusia tidak terlepas dari sarana transportasi sebagai moda dalam kegiatan sehari-hari. Vice President Corporate Development PT. Pertamina Lubricants, Mohamad Zuchi menyampaikan mengutip data Badan Pusat Statistik: “...jumlah kepemilikan kendaraan beroda empat di Indonesia tahun 2018 mencapai 24,6 juta. Masingmasing 15,8 juta untuk mobil penumpang, serta 8,8 juta untuk bus dan truk." Hal ini menciptakan peluang bisnis yang besar bagi dunia asuransi kerugian, khususnya bagi asuransi kendaraan bermotor. Semakin banyak masyarakat yang ingin mengasuransikan kendaraannya, hal ini terkait dengan semakin tingginya risiko yang akan dihadapi oleh para pemilik kendaraan. Semakin banyak masyarakat menggunakan kendaraan bermotor untuk berpergian baik di dalam kota, maupun keluar kota. Disisi lain pesatnya perkembangan teknologi saat ini, menuntut perusahaan untuk dapat berubah mengikuti perkembangan yang ada. Perubahan ini menuntut perusahaan untuk mampu beradaptasi terhadap perubahan yang ada.

Asuransi Astra adalah perusahaan yang bergerak dibidang jasa asuransi kerugian, khususnya kendaraan bermotor. Dalam bisnis asuransi umum/kerugian, surveyor sebagai salah satu sumber daya manusia dalam perusahaan asuransi 
memegang peranan penting dalam proses mengambil keputusan dan menggunakan teknologi yang ada tersebut.

Untuk menghadapi perkembangan dan perubahan itu dibutuhkan suatu manajemen kinerja di bagian surveyor, untuk menciptakan layanan yang simple dan memuaskan bagi para customer. Surveyor perlu meningkatkan kompetensinya agar dapat mengetahui karakteristik dan spesifikasi kendaraan yang akan disurvey sehingga dapat melakukan analisa dengan baik dan memberikan keputusan dengan benar sesuai dengan KPI (Key Performance Indcator) yang telah ditetapkan.

Untuk mengantisipasi perubahanperubahan lingkungan organisasi yang cepat dan dinamis, praktik manajemen kinerja baru dilakukan penyesuaianpenyesuaian melalui perbaikan berkelanjutan yang tanpa mengenal lelah dan tidak mempunyai akhir. Model manajemen kinerja yang terdiri dari empat tahap (perencanaan, implementasi, refleksi, dan kompensasi) dapat digunakan untuk perbaikan berkelanjuatan. Manajer dan supervisor bersama semua karyawan akan menggunakan praktik manajemen kinerja sebagai alat untuk memberikan kontribusi terhadap penentuan bentuk dan tujuan organisasi baru yang dinamis.

Hal ini membutuhkan sumber daya manusia yang kompeten yang memiliki semangat, kedisiplinan, dan integritas yang baik untuk mencapai tujuan perusahaan yang telah ditetapkan. Dengan integritas yang baik, seorang surveyor memiliki "value" di dalam perusahaan sehingga dapat diandalkan untuk bekerja sesuai yang telah ditentukan oleh perusahaan. Satu-satunya faktor yang menunjukkan keunggulan kompetitif dalam bisnis global adalah potensi sumber daya manusia (SDM) yang berkualitas. (Emron Edison, dkk, 2017: 3).

Idealnya, setiap perusahaan memiliki budaya organisasi, yang merupakan sebuah sistem nilai yang terbentuk dari kesepakatan kolektif dari semua pihak dalam perusahaan atau organisasi. Kesepakatan disini adalah dalam hal cara pandang tentang bekerja dan unsurunsurnya.

Budaya yang kuat serta pengelolaan SDM yang baik dapat menjadi alat perusahaan untuk berkompetisi dengan pesaing. Karena dari budaya yang kuat ini akan meningkatkan perilaku yang konsisten yang dapat menciptakan efektifitas organisasi yang dipengaruhi oleh kinerja karyawan. Sedangkan bila budaya tersebut tidak kuat, maka tujuan organisasi akan berjalan ke arah yang salah. (Kotter \& Heskett, dalam Darmawiyanti, 2008). Jika budaya suatu organisasi tidak memberikan hal yang positif bagi organisasi tersebut, maka akan berdampak pada kinerja organisasi yang buruk, karena budaya perusahaan menginformasikan kepada karyawan tetang bagaimana perilaku karyawan yang semestinya. Budaya organisasi menjadi identitas sebuah organisasi yang mempengaruhi bagaimana orang-orang berbuat dalam organisasi. Sehingga jika budaya organisasi baik, maka tidak mengherankan jika anggota organisasi adalah orang-orang yang baik dan berkualitas pula.

\section{Kajian Teori}

Budaya organisasi dapat digambarkan sebagai nilai, norma dan artefak yang diterima oleh anggota organisasi sebagai iklim organisasi ia akan mempengaruhi dan dipengaruhi strategi organisasi, struktur dan system organisasi. Budaya organisasi adalah seperangkat norma, persepsi, pola perilaku yang diciptakan atau dikembangkan dalam sebuah organisasi untuk mengatasi asumsi atau pandangan dasar ini diyakini karena telah berjalan baik dalam organisasi, sehingga dianggap bernilai positif dan pantas diajarkan kepada karyawan baru sebagai cara yang tepat untuk berpikir dan bertindak dalam menjalankan tugas.

Secara umum budaya organisasi didefinisikan sebagai serangkaian tata 
nilai, keyakinan, dan pola-pola perilaku yang membentuk identitas organisasi serta perilaku para anggotanya. Budaya organisasi berkaitan dengan bagaimana karyawan memahami karakteristik budaya suatu organisasi, dan tidak terkait dengan apakah karyawan menyukai karakteristik itu atau tidak. Budaya organisasi adalah suatu sikap deskriptif, bukan seperti kepuasan kerja yang lebih bersifat evaluatif.

Budaya organisasi adalah pola asumsi dasar bersama yang dipelajari oleh kelompok saat memecahkan masalahmasalah adaptasi ekstern dan integrasi internal yang telah berfungsi dengan cukup baik untuk bisa dianggap benar dan untuk bisa diajarkan kepada anggota kelompok baru sebagai cara yang benar untuk menerima sesuatu, berfikir dan merasakan dalam hubungannya dengan masalah-masalah tersebut.

Organisasi memiliki budaya sendirisendiri yang sifatnya spesifik, karena kenyataan menunjukkan bahwa setiap organisasi mempunyai kepribadian yang khas (Carrel, et, al, 1997) dalam M. Arifin (2010:111). Budaya dapat sangat stabil sepanjang waktu, tetapi budaya juga tidak pernah statis. Krisis terkadang mendorong kelompok untuk mengevaluasi kembali beberapa nilainilai atau perangkat, praktis. Tantangantantangan baru dapat mengakibatkan penciptaan cara-cara baru untuk melakukan segala sesuatunya.

Budaya organisasi sebagai kerangka kognitif yang berisi sikap, nilai dan keyakinan terhadap organisasi (Moeljono, 2005). Budaya organisasi adalah kepribadian perusahaan yang tumbuh oleh sistem nilai yang menimbulkan norma yang mengenai perilaku yang tercermin dalam persepsi, sikap dan perilaku orangorang yang ada di dalam organisasi ataupun perusahaan tersebut dengan demikian budaya mempengaruhi sebagian besar aspek kehidupan organisasi atau perusahaan (Muis et al., 2018).
Budaya organisasi yang benar-benar dikelola sebagai alat manajemen akan berpengaruh dan menjadi pendorong bagi pegawai untuk berperilaku positif, dedikatif dan produktif. Nilai-nilai budaya itu tidak nampak, tetapi merupakan kekuatan yang mendorong perilaku untuk menghasilkan efektivitas kerja (Sutrisno, 2010). Hasil penelitian Gultom (2014), dan (Muis etal., 2018), Andayani \& Tirtayasa (2019) dalam penelitiannya mengungkapkan bahwa budaya organisasi berpengaruh positif dan signifikan terhadap kinerja pegawai.

Kualitas sumber daya manusia (SDM) dalam diri seseorang secara teoritis juga dapat berpengaruh pada kinerja pegawai tersebut. Salah satu indikator kualitas SDM adalah keahlian (Skill) yang di miliki oleh pegawai, kinerja seorang pegawai baik apabila ia memiliki keahlian (skill) yang tinggi. Tampubolon, (2007 :hal 50). Hal ini bearti dengan kualitas SDM yang lebih baik akan memiliki kinerja yang baik pula, sehingga terdapat korelasi positif antara kualitas SDM dengan kinerja pegawai. SDM merupakan faktor yang sangat penting dalam sebuah organisasi, karena manusia selalu berperan aktif dan dominan dalam setiap kegiatan organisasi dimulai dari perencanaan, pelaku dan penentu terwujudnya tujuan organisasi, sehingga dapat dikatakan bahwa tujuan organisasi akan terealisasi apabila di tunjang SDM yang berkualitas. Hal ini di perkuat oleh pernyataan Siagian, (2009 : 02) yang menyatakan bahwa ketergantungan organisasi pada manajemen sumber daya manusia yang semakin bermutu tinggi akan semakin besar pula, tanpa mengurangi pentingnya perhatian yang tetap harus di berikan pada manajemen sumber-sumber organisasi lainnya, tidak bisa disangkal bahwa perhatian utama tidak bisa tidak harus diberikan pada manajemen sumber daya manusia. Untuk mewujudkan situasi demikian, perlu peningkatan kesadaran tentang maksud dari semua kegiatan manajemen sumber 
daya manusia terhadap keberhasilan organisasional.

\section{METODE}

Penelitian ini menggunakan metodologi kualitatif dengan pendekatan naratif, karakter alami (natural setting) dimana sumber data didapat secara langsung dan deskriptif. Analisis dilakukan secara naratif dan makna merupakan hal yang esensial.

\section{HASIL DAN PEMBAHASAN}

Penelitian ini dilakukan di bagian surveyor di kantor cabang Asuransi Astra Buana di wilayah Jatabek. Penelitian dilakukan menggunakan metode kualitatif dengan pendekatan naratif, yaitu mengamati proses kerja yang dilakukan oleh seorang surveyor sejak awal bergabung menjadi karyawan di PT. Asuransi Astra Buana.

Berdasarkan definisi dan fungsi surveyor, maka seorang surveyor harus memiliki kemampuan teknik otomotif, kemampuan analisa, dan kemampuan komunikasi yang baik sebagai dasar pelayanan (service) terhadap pelanggan.

Berdasarkan analisa SWOT yang dilakukan, untuk memanfaatkan potensi yang ada untuk guna meraih peluang, Asuransi Astra Buana dapat melakukan strategi sebagai berikut:

a. Pemanfaatan budaya perusahaan yang baik dan kemampuan SDM yang dimiliki untuk menghasilkan layanan yang terbaik.

b. Pemanfaatan pengalaman manajemen dan dukungan dari grup untuk menambah jumlah pelanggan.

c. Pemanfaatan peraturan dan perundangan dengan integritas yang dimiliki utuk mendapatkan kepercayaan dari pelanggan.
Analisa SWOT

\begin{tabular}{|c|c|c|}
\hline & STRENGTHS & WEAKNESS \\
\hline & Budaya persushahan yang baik & Kualitas pelayanan \\
\hline & Pengalaman manajemen & Sistem Karyawan kontrak \\
\hline & Dukungan perrusahaan besar & Program pendidikan dan pelathan \\
\hline EFAS & Kemampuan SDM & Rate premin ingoi \\
\hline & Meniliki integitas & \\
\hline OPPORTUNITIES & STRATEGISO & STRATEGIWO \\
\hline Meningkatuya industri otomotif & $\begin{array}{l}\text { Pemanfaatan budaya pertusahaan } \\
\text { yang baik dan kemampuan SDM } \\
\text { untuk menghasilkan layanan yang } \\
\text { terbaik } \\
\end{array}$ & $\begin{array}{l}\text { Perencanaan perbaikan program pendidikan } \\
\text { dan pelathan yang berorientasis pada } \\
\text { perbaikan kualitas layanan untuk } \\
\text { meningkaktkan kinerja surveyor } \\
\end{array}$ \\
\hline Perilaku bisnis & $\begin{array}{l}\text { Pemanfaatan pengalaman } \\
\text { manajemen dan dukungan dari grup } \\
\text { untuk menambah jumlah pelangogan }\end{array}$ & 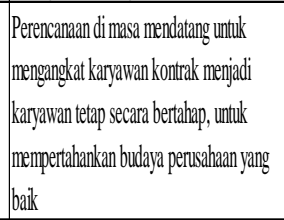 \\
\hline Customer & $\begin{array}{l}\text { Pemanfaatan peraturan dan } \\
\text { perundangan dengan integitas yang } \\
\text { dimiliki untuk mendapatkan } \\
\text { kepercayaan dari pelangogan } \\
\end{array}$ & \\
\hline Peraturan \& Pernundangan & & \\
\hline THREATS & STRATEGIST & STRATEGI WT \\
\hline Kondisis sosial, ekonomi, politik & 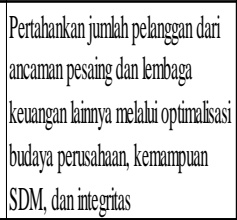 & 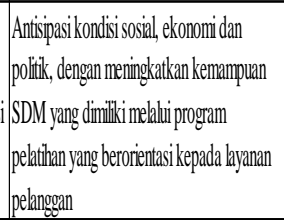 \\
\hline Persaingan & $\begin{array}{l}\text { Pertahankan jumlah pelanggan } \\
\text { dengan memberi kemudahan } \\
\text { teknobogi }\end{array}$ & $\begin{array}{l}\text { Antispasipersaingan daripesaing dengan } \\
\text { senanniasa memperthanankan kualtias } \\
\text { pelayanan }\end{array}$ \\
\hline Perubahan teknobog & $\begin{array}{l}\text { Memberikan pengetantuan kepada } \\
\text { pihak huar mengenai asurannsi dan isi } \\
\text { dari perjanjian (polis) } \\
\end{array}$ & $\begin{array}{l}\text { Pengurangan sistem kontrak agar SDM } \\
\text { dapat ebih loyal dalam menghadalapi } \\
\text { persaingan }\end{array}$ \\
\hline Perilaku phak ekstermal & & $\begin{array}{l}\text { Memberkan benefit dari produk asuruansi } \\
\text { yango ditawarkan }\end{array}$ \\
\hline Lembaga keluangan lamnya & & \\
\hline
\end{tabular}

Memiliki budaya yang kuat merupakan pekerjaan besar bagi perusahaan dan menjadi keinginnan bagi setiap perusahaan. Prosesnya tentu tidak mudah, apalagi dengan terciptanya budaya yang sudah mengakar di lingkungan kerjanya yang dibawa dari masing-masing anggota organisasi. Perusahaan perlu mengambil tindakan dengan menyediakan dana dan menginvestasikan setiap individu untuk berkesempatan belajar. Budaya yang unggul dapat diciptakan dengan membiasakan elemen-elemen pentingnya 
secara berkelanjutan. Proses ini tidak hanya diterapkan pada karyawan, tetapi juga pada para pemimpinnya, yang bisa dilakukan melalui pelatihan yang terencana dengan baik ataupun pembelajaran dengan berbagi pengalaman dengan perusahaan lain yang memiliki budaya yang kuat dan unggul.

Manajemen kinerja membutuhkan partispasi baik dari atasan maupun bawahan untuk mengembangkan program kerja menuju pencapaian tujuan organisasi. Dengan berpartisipasi secara efektif dalam kerangka kerja manajemen kinerja oleh berbagai pihak dalam perusahaan, maka diharapkan perusahaan berkinerja tinggi bukan sekedar impian semata.

Pengembangan budaya organisasi dapat berlangsung antara lain apabila dalam organisasi terdapat budaya yang bersifat mendorong kinerja (Faizal et al., 2019), (Rosvita, Setyowati, Fanani (2017). Menurut Victor Tan (Wibowo: 2010) karakteristik budaya organisasi meliputi: (a) Inisiatif individual; (b) Toleransi terhadap risiko; (c) Arah sasaran yang jelas; (d) Integrasi yang terkoordinasi; (e) Dukungan manajemen; (f) Pengawasan perilaku karyawan; (g) Identitas organisasi; (h) Sistem penghargaan; (i) Toleransi terhadap konflik. Kinerja (performance) mengacu kepada kadar pencapaian tugas-tugas yang membentuk sebuah pekerjaan pegawai (Sulaeman, 2018). Kinerja merefleksikan seberapa baik pegawai memenuhi persyaratan sebuah pekerjaan. Sering disalah tafsirkan sebagai upaya (effort), yang mencerminkan energi yang dikeluarkan, kinerja diukur dari segihasil (Parmitasari, Abdullah \& Nirwana 2017). Penelitian ini dilaksanakan merupakan bentuk kajian dari beberapa peneliti terdahulu yang mengkaji mengenai sumberdaya manusia, budaya organisasi, serta kualitas kinerja. Hasil penelitian yang dilaksanakan oleh Dahlan, Hasim, Hamdan (2017) menunjukkan gaya kepemimpinan dan budaya Organisasi berpengaruh positif dan signifikan terhadap kinerja karyawan melalui kepuasan kerja karyawan. Gaya

\section{KESIMPULAN}

Setelah dilakukan pembahasan dan analisa terhadap hasil wawancara dan observasi mengenai bagaimana kinerja surveyor di PT. Asuransi Astra Buana, maka dapat diperoleh kesimpulan sebagai berikut:

1. Manajemen Kinerja Surveyor.

Pola manajemen kinerja surveyor sudah berjalan melalui metode PDCA. Perencanaan (Plan) disusun pada tengah tahun sebelumnya dalam bentuk activity plan, kemudian dikumpulkan dalam wadah planning cycle. Tindakan (Do) dalam bentuk komitmen (action) yang di launching di awal tahun berikutnya pada acara surveyor gathering. Monitor (Check) yang dilakukan oleh supervisor secara daily maupun mingguan terkait loading Bengkel, cost claim, panel replace dan panel repair, kemudian Review yang dilakukan secara mingguan (weekly) melalui meeting koordinator ataupun quarterly melalui meeting all surveyor jatabek. Hasil dari monitoring ini diterapkan (Action) kembali dalam pekerjaan sehari-hari sesuai target yang telah ditetapkan.

2. Budaya Perusahaan.

Budaya perusahaan (core value) di perusahaan ini berjalan dengan baik dan diterapkan dalam pekerjaan sehari-hari oleh surveyor. Untuk lebih mengaplikasikan budaya perusahaan ini, dibuat tagline $7 \mathrm{sb}$ (7 sexy behavior) yang terdiri dari:
a. Tersenyum.
b. Menyapa.
c. Menyebut nama.
d. Antusias.
e. Informatif.
f. Helpful \& Solutif.
g. Personal touch.

Sehingga diharapkan surveyor dapat mengaplikasikan $7 \mathrm{sb}$ ini dalam pekerjaannya sehari-hari agar 
menciptakan suasana yang ramah, akrab dan memberikan pelayanan yang berkesan. Selain itu penerapan budaya perusahaan ini juga didukung dengan sistem yang digunakan oleh surveyor dalam bekerja, sehingga memudahkan proses kerja surveyor dan menciptakan layanan yang simple bagi pelanggan.

3. Implementasi penerapan budaya perusahaan dalam menunjang kinerja surveyor.

Secara keseluruhan, kinerja surveyor akan di evaluasi secara quarterly dan pada akhir tahun. Dari hasil evaluasi ini akan terlihat performance surveyor dan juga sebagai pertimbangan dalam menentukan target di tahun berikutnya. Walapun dari data yang ada kinerja surveyor belum sesuai target yang direncanakan, namun dari sisi layanan, customer Asuransi Astra Buana masih merasa puas dengan layanan yang diberikan surveyor Asuransi Astra Buana. Hal ini berkat implementasi budaya perusahaan yang diterapkan dalam pekerjaan sehari-hari dalam layanan kepada customer melalaui tagline $7 \mathrm{sb}$.

Berdasarkan analisa SWOT yang dilakukan, maka salah satu strategi yang perlu dijalankan oleh Asuransi Astra Buana adalah memanfaatkan budaya perusahaan yang baik dan kemampuan SDM yang dimiliki untuk menghasilkan layanan yang terbaik pagi pelanggan dan juga meningkatkan kinerja surveyor. Dengan budaya layanan yang terbaik ini dapat memberikan nilai bagi para pelanggan dan para pelanggan pun dapat berperan sebagai "agen" dalam mempromosikan layanan yang mereka alami kepada orang lain yang akan berasuransi. Sehingga Asuransi Astra Buana memiliki nilai lebih untuk mempertahankan pelanggan yang sudah ada dan untuk mendapatkan pelanggan baru.
Berdasarkan hasil penelitian yang telah dilakukan maka penulis mengajukan beberapa saran untuk menyempurnakan keterbatasan yang ada, yaitu sebagai berikut:

1. Pengelolaan manajemen kinerja yang baik di surveyor agar dapat dipertahankan dan dijalankan secara konsisten. Pemberian training/refreshment knowledge bagi surveyor adalah sesuatu yang mutlak diperlukan untuk mendapat tambahan pengetahuan baru disamping melakukan penyegaran terhadap pekerjaan seharihari yang telah dilakukannya dan juga dapat menjadi sarana diskusi untuk membahas permasalahan-permasalahan yang ada di lapangan serta solusinya.

2. Untuk mendukung manajemen kinerja yang baik, diperlukan juga adanya innovasi dalam setiap pekerjaan. Terutama ide-ide agar perusahaan dapat tetap berjalan dengan baik, dapat memberikan layanan yang lebih mudah (simple) dan mengesankan (memorable) kepada pelanggan dan karyawan dapat memberikan manfaat bagi perusahaan.

3. Penggunaan peralatan kerja yang sesuai dengan kondisi dan teknologi saat ini, untuk mendukung kinerja surveyor dan juga dapat memberikan layanan yang mudah (simple) bagi pelanggan juga memberikan rasa nyaman (peace of mind).

4. Budaya perusahaan perlu dikenalkan kepada seluruh karyawan secara terus menerus dan berkesinambungan, agar tetap terjaga dalam memberikan layanan yang baik kepada pelanggan. Sehingga visi perusahaan "we bring peace of mind" dapat tercapai.

5. Peningkatan budaya disiplin, jujur, dan bertanggung jawab harus terus ditingkatkan sebagai bagian dari budaya perusahaan. Penandatanganan pakta integritas merupakan salah satu cara untuk menjaga komitmen kerja surveyor. Hal ini terkait penerapan budaya perusahaan dan juga menunjang manajemen kinerja surveyor. 


\section{DAFTAR PUSTAKA}

Anwar Prabu Mangkunegara, A.A. (2005), Perilaku dan Budaya Organisasi, Refika Aditama, Bandung.

Asuransi Astra, (2016), Junior Surveyor Hard Competency Training, Jakarta.

Creswell, John W, (2015), Penelitian Kualitatif \& Desain Riset, Pustaka Pelajar, Yogyakarta.

Emron Edison, dkk, (2017), Manajemen Sumber Daya Manusia, Alfabeta, Bandung.

Mia Lasmi Wardiah, (2016), Teori Perilaku dan Budaya Organisasi, Pustaka Setia, Bandung
Sugiyono, (2017), Metode Penelitian Kuantitatif, Kualitatif, dan $R \& D$, Alfabeta, Bandung.

Faizal, R., Sulaeman, M., \& Yulizar, I. (2019). Pengaruh Budaya, Motivasi

Kerja Dan Kompetensi Terhadap Kinerja Karyawan. EBA Journal:

Journal Economics, Bussines and Accounting, 5(1), 11-21.

https://doi.org/10.32492/eba.v5i1.706

Sulaeman, M. (2018). Pengaruh Orientasi

Kewirausahaan, Orientasi Pasar, Dan

Inovasi Produk Terhadap Kinerja

Pemasaran (Studi Pada Industri Tahu Di

Sentra Industri Tahu Kota Banjar).

Jurnal Ilmiah Administrasi Bisnis Dan Inovasi, 2(1), 153-165.

https://doi.org/10.25139/jai.v2i1.909 